Килочицкая Наталия, Стеценко Ольга. Изменения количественного и качественного состава антропофильных видов кровососущих комаров Каневского природного заповедника. Каневский природный заповедник ежегодно является базой проведения летней учебной практики студентов. Одним из факторов опасности считаются комары - переносчики трансмиссивных заболеваний.

Климатические условия (температура, осадки) в сравниваемые годы на территории заповедника заметно отличались (2006 - влажный и умеренно теплый; а 2015 - сухой и жаркий). Следствием этого стали различия в формировании личиночных биотопов, повлекшие изменения видового состава и численности имаго комаров.

Если в 2006 г. на территории заповедника зарегистрировано 17 видов комаров из трех родов (преобладали моноциклические виды), то в 2015 г. количество видов составило 14, но из шести родов (с явным преобладанием полициклических видов).

Место доминирующего в 2006 г. Aedes vexans в 2015 г. занял Culex modestus. Также на территории заповедника впервые зарегистрирована Culiseta alaskaensis.

Ключевые слова: кровососущие комары; изменения климата; Каневский природный заповедник.

Kilochitska Nataliya, Stetsenko Olga. Qualitative and Quantitative Changes in Compositions of Species of Antropofilious Mosquitoes in the Kanev Natural Reserve. Kanev Nature Reserve is the base for the students' annual summer practical training. One of the risk factors are mosquitoes which are carriers of the vector-borne diseases.

During the years of comparison, the climatic conditions (e.g. temperature, precipitation) in the reserve were significantly different (in 2006 - humid and moderately warm, and in 2015 - dry and hot). As a consequence there appeared differences in formation of larval habitats, which induced changes in the composition of species and the quantity of adult mosquitoes.

While in 2006 the 17 species of mosquitoes from 3 genera (with domination of the monocyclic species) were recordedin the territory of the reserve, in 2015 the number of species became 14 from 6 genera (with a clear domination of the polycyclic species).

The dominant position of Aedes vexans in 2006 was taken by Culex modestus in 2015. Culiseta alaskaensis was also recorded in the territory of the reserve for the first time.

Key words: mosquitoes; climate change; Kanev Natural Reserve.

Стаття надійшла до редколегії 19.10.2015 p.

УДК 591.5: 594.1

Агнеса Стадниченко, Дмитро Вискушенко

\title{
Вплив купрум сульфату водного середовища на частоту серцебиття перлівницевих (Mollusca, Bivalvia, Unionidae)
}

Розглянуто вплив різних концентрацій $(0,1,1,10$ мг/дм³ $)$ купрум сульфату водного середовища на частоту серцебиття трьох видів перлівницевих. 3'ясовано, що за 0,1 мг/дм ${ }^{3}$ токсиканту у всіх досліджених молюсків ритм серцевих скорочень прискорюється. Зі збільшенням концентрації купрум сульфату у воді до 1, а потім до 10 мг/дм ${ }^{3}$ у цих тварин розвивається прогресуюча брадикардія.

Ключові слова: перлівницеві, купрум сульфат, частота серцебиття.

Постановка наукової проблеми та її значення. Сьогодні полютанти, які містять іони важких металів, є одними $з$ найпоширеніших забруднювачів як природного, так і штучного водного середовища. Це високотоксичні елементи [1], котрі дуже довго зберігаються в довкіллі. Вони наявні в стічних водах рудничного й шахтного виробництв, а також металообробних, машинобудівельних, хімічних, гальванічних підприємств. Нерідко іони міді $є$ компонентами й сільськогосподарських забруднень.

Гранично допустима їх концентрація у водоймах санітарно-гігієнічного призначення 0,1 мг/дм ${ }^{3}$, а у водоймах рибогосподарського призначення - 0,01 мг/дм². Варто зазначити, одначе, що значення другого 3 них установлено щодо риб, а через це нешкідливі для останніх концентрації токсикантів можуть виявитися згубними для інших гідробіонтів. До того ж у місцях випускання ски-

(ㄷ) Стадниченко А., Вискушенко Д., 2015 
дів у гідромережу концентрація забруднювальних речовин нерідко перевищує значення рибогосподарських ГДК на кілька порядків. Тому актуальним вважаємо дослідження впливу на водні організми і вищих за ГДК концентрацій забруднювальних речовин на різні їх тест-функції. Адже без цього неможливо встановити екологічно нейтральні значення різних речовин - забруднювачів водотоків і водойм. Лише за такого підходу можливе достовірне визначення значень екологічних ГДК, застосування яких дасть змогу всім компонентам гідробіоценозів забезпечити умови екологічного комфорту [2].

Формулювання мети й завдання статті. Мета дослідження - 3' ясування особливостей впливу різних концентрацій купрум сульфату водного середовища на частоту серцебиття перлівницевих.

Аналіз досліджень проблеми. На сьогодні з цього питання є лише єдине дослідження, датоване останньою чвертю XX ст. [3]. Його проведено на трьох видах перлівниць (Unio pictorum ponderosus, $U$. rostratus gentilis, U. conus borysthenicus) й одному виді жабурниці (Anodonta cygnea) із застосуванням у токсикологічному експерименті розчинів купрум сульфату $\left(0,1,1,10\right.$ мг/дм $\left.{ }^{3}\right)$. 3'ясовано, що за 0,1 мг/дм ${ }^{3}$ токсиканту у водному середовищі у всіх піддослідних тварин виникає тахікардія. Збільшення ж його концентрації на 1-2 порядки спровоковує в них розвиток прогресуючої брадикардії, котра в найважчих випадках призводить до летальних наслідків.

За чверть століття, що минуло з моменту отримання наведених вище відомостей, численних негативних змін зазнала гідромережа Житомирщини через потужне зростання впливу на неї антропогенного тиску. Високопродуктивні колись річкові малакоценози перетворилися на низькопродуктивні внаслідок перебігу в їхніх біотопах регресивних сукцесій. Цим дослідженням його автори прагнули з'ясувати, наскільки це відбилося на токсикорезистентності перлівницевих.

Матеріал і методи досліджень. Використано 1327 екз. перлівницевих Unio conus borysthenicus Kobelt, 1879, U. rostratus rostratus (Lamarck, 1819), Colletopterum piscinale falcatum (Drouët, 1881), зібраних у липні - вересні 2011 р. в р. Тетерів на відтинку їі поміж селами Перлявка й Денеші (Житомирська обл.). До лабораторії молюсків транспортували обгорнутими вологою мішковиною, складеною в 5-6 шарів. Аклімацію тварин (15 діб) проводили в акваріумах ємністю 200 л (щільність посадки молюсків 4 екз./л), заповнених дехлорованою відстоюванням (доба) водопровідною водою (ії температура $21-23^{\circ} \mathrm{C}, \mathrm{pH}-7,5-8$, уміст кисню - 8,3-8,9 мг/л).

По завершенню аклімації в стулках черепашок попередньо промаркірованих тварин, користуючись ножівкою, випилювали безпосередньо над їхнім серцем «віконце» $(1,5 \times 1,5$ см). Фістульних особин протягом 30 хв утримували в заповнених водою кюветах задля стабілізації в них частоти серцебиття. Значення останньої встановлювали візуально за допомогою секундоміра. Підрахунок ударів серця за 1 хв у кожної особини здійснювали тричі. Для аналізу отриманих таким чином кількісних показників використовували їхні середні значення. Цей дослід слугував контролем для токсикологічного дослідження.

Як токсикант використано п'ятиводний купрум сульфат $\left(\mathrm{CuSO}_{4} \times 5 \mathrm{H}_{2} \mathrm{O}\right)$. В орієнтовному токсикологічному досліді, поставленому за В. А. Алексєєвим [4], установлено значення двох токсикологічних показників $\left(\mathrm{LC}_{0} \mathrm{i} \mathrm{LC}_{100}\right)$, а в їх межах підібрано концентрації, котрі застосовувалися переважно протягом токсикологічного досліду $(0,1,1,10$ мг/дм³ $)$. Піддослідних фістульних тварин 30 хв витримували в кюветах із розчинами купрум сульфату відповідної концентрації, після чого знімали результати (таким самим способом, як і в контрольному досліді).

У разі необхідності (за неможливості візуального визначення) стать досліджуваних особин установлювали за допомогою мікроскопіювання (МБР, зб.7×8) тимчасових гістологічних препаратів, виготовлених із тканин їхніх гонад.

Кількісні результати дослідів опрацьовано методами базової варіаційної статистики $[5,6]$.

Виклад основного матеріалу й обгрунтування отриманих результатів дослідження. 3' ясовано, що в нормі частота серцевих скорочень у молюсків усіх досліджених видів майже однакова (табл. 1). Статистично вірогідна різниця за цим показником між самцями й самками відсутня. Проте все ж таки в самців постежено тенденцію до деякого прискорення серцебиття, що може свідчити про дещо більшу їхню чутливість до цього токсиканта, порівняно із самками.

У середовищі з 0,1 мг/дм ${ }^{3}$ купрум сульфату відзначено статистично вірогідне прискорення серцебиття (табл. 1): у самок - в 1,2-1,3 раза й в 1,1 раза - у самців (Р >94,5 \%). Це, напевне, пов'язано 3 тим, що за цієї концентрації токсиканта проявляється його в'яжуча дія, через що вповільнюється робота війок миготливого епітелію, що вкриває філаменти зябер молюсків. Це простежено в інших двостулкових молюсків [7]. На думку В. В. Хлєбовича [8], токсиканти, які вражають зябровий епі- 
телій молюсків, являють собою важливий чинник, що призводить до розвитку в них гіпоксії. Це ж, зі свого боку, активізує в них відповідні захисно-пристосувальні механізми. Доведено [9, 10], що за отруєння молюсків токсикантами і розвитку в них унаслідок цього гіпоксії одним із проявів захиснопристосувального процесу є піднесення рівня загального обміну речовин.

Таблиия 1

Вплив різних концентрацій купрум сульфату водного середовища на ритм серцебиття (yd./xв) у перлівницевих

\begin{tabular}{|c|c|c|c|c|c|c|c|c|c|}
\hline \multirow{2}{*}{$\begin{array}{c}\mathrm{C} \\
\mathrm{CuSO}_{4}, \\
\mathrm{Mz}^{2} / \partial \boldsymbol{m}^{3}\end{array}$} & \multicolumn{3}{|c|}{ U. rostratus } & \multicolumn{3}{|c|}{ U. conus } & \multicolumn{3}{|c|}{ C.piscinale } \\
\hline & $\mathbf{n}$ & Стать & $\begin{array}{c}\mathbf{M} \pm \mathbf{m} \\
\mathbf{V}\end{array}$ & $\mathbf{n}$ & Стать & $\underset{\mathbf{V}}{\mathbf{M} \pm \mathbf{m}}$ & $\mathbf{n}$ & Стать & $\underset{\mathbf{M}}{\mathbf{V} \pm \mathbf{m}}$ \\
\hline \multirow{2}{*}{0} & 41 & Самки & $\begin{array}{c}9,69 \pm 0,81 \\
15,41\end{array}$ & 39 & Самки & $\begin{array}{c}9,48 \pm 0,63 \\
19,34\end{array}$ & 67 & Самки & $\begin{array}{c}9,83 \pm 0,51 \\
17.59\end{array}$ \\
\hline & 36 & Самці & $\begin{array}{c}10,58 \pm 0,09 \\
20,21\end{array}$ & 43 & Самці & $\begin{array}{c}10,45 \pm 0,33 \\
21,11\end{array}$ & 70 & Самці & $\begin{array}{c}10,63 \pm 0,62 \\
18,46\end{array}$ \\
\hline \multirow{2}{*}{0,1} & 27 & Самки & $\begin{array}{c}11,88 \pm 0,11 \\
14,31\end{array}$ & 73 & Самки & $\begin{array}{c}11,96 \pm 0,72 \\
15,15\end{array}$ & 53 & Самки & $\begin{array}{c}12,16 \pm 0,08 \\
18,43\end{array}$ \\
\hline & 75 & Самці & $\begin{array}{c}11,66 \pm 0,54 \\
10,44\end{array}$ & 66 & Самці & $\begin{array}{c}11,87 \pm 0,09 \\
13,56\end{array}$ & 38 & Самці & $\begin{array}{c}12,31 \pm 0,03 \\
20,01\end{array}$ \\
\hline \multirow{2}{*}{1} & 44 & Самки & $\begin{array}{c}8,75 \pm 0,19 \\
7,14\end{array}$ & 37 & Самки & $\begin{array}{c}9,12 \pm 0,21 \\
13,22\end{array}$ & 50 & Самки & $\begin{array}{c}11,01 \pm 0,09 \\
18,75\end{array}$ \\
\hline & 53 & Самці & $\begin{array}{c}8,63 \pm 0,08 \\
20,12\end{array}$ & 85 & Самці & $\begin{array}{c}9,69 \pm 0,08 \\
18,17\end{array}$ & 29 & Самці & $\begin{array}{c}10,97 \pm 0,16 \\
16.04\end{array}$ \\
\hline \multirow{2}{*}{10} & 61 & Самки & $\begin{array}{c}6,29 \pm 0,03 \\
16,00\end{array}$ & 34 & Самки & $\begin{array}{c}7,15 \pm 0.04 \\
20,05\end{array}$ & 49 & Самки & $\begin{array}{c}6,51 \pm 0,15 \\
18,92\end{array}$ \\
\hline & 57 & Самці & $\begin{array}{c}5,60 \pm 0,04 \\
15,23\end{array}$ & 65 & Самці & $\begin{array}{c}6,32 \pm 0,06 \\
14,81\end{array}$ & 35 & Самці & $\begin{array}{c}6,12 \pm 0,03 \\
18,53\end{array}$ \\
\hline
\end{tabular}

Яскраве свідчення цього - зростання частоти їхнього серцебиття. Інтенсифікація роботи серця молюсків свідчить про те, що за концентрації 0,1 мг/дм³ купрум сульфату у водному середовищі в підданих його дії тварин розвивається патологічний процес - отруєння їхнього організму, а саме його друга фаза ${ }^{11} /$ - фаза стимуляції. На цій фазі відбувається мобілізація захисно-пристосувальних властивостей організму перлівницевих, скерована на компенсацію отриманих ним ушкоджень. Тобто зростання частоти серцебиття за таких обставин - це компенсаційна тахікардія.

За перебування молюсків у середовищі зі вмістом у ньому купрум сульфату в кількості 1 мг/дм ${ }^{3}$ у всіх піддослідних тварин відбувається істотне зменшення частоти серцебиття (Р>99,9\%). У них відзначено поглиблення морфофункціональних зрушень зябрового епітелію через посилення його слизовидільної функції й утворення альбумінатів (припікаюча дія токсиканта). За таких обставин функціональні можливості зябер перлівницевих набагато погіршуються, а захисно-пристосувальний механізм у формі інтенсифікації загального обміну речовин виявляється неспроможним подолати шкодочинність токсиканта. Виходячи 3 характеру та ступеня прояву згаданих вище зрушень, зареєстрованих у перлівницевих за дії на них купрум сульфату водного середовища в концентрації 1 мг/дм доходимо висновку, що загальний їх стан відповідає депресивній фазі патологічного процесу. Утім, одначе, не виключено, що саме на фазі депресії в них «вмикається» інший захисно-пристосувальний механізм, а саме перехід цих тварин від аеробного дихання до дихання анаеробного. Відомо [10], що останнє $є$ одним із найважливіших біохімічних пристосувань гідробіонтів до перебування в токсичному середовищі, яке дає їм змогу протягом якогось часу зберігати життєздатність, хоча й на дещо нижчому рівні, ніж за здійснення дихання аеробного.

\footnotetext{
${ }^{1}$ Градацію патологічного процесу прийнято за [11].
} 
За збільшення концентрації купрум сульфату в токсичному середовищі 31 до 10 мг/дм³ відбувається прогресуюче зниження частоти серцебиття у всіх використаних у дослідженні перлівницевих (в 1,3-1,4 paза у U. rostratus i у U. conus i в 1,7 раза - у C. piscinale) ( $>>99,9 \%$ ). Це зумовлено глибокими руйнівними наслідками дії токсиканта на миготливий і слизовий епітелії їхнього зябрового апарату. При цьому різко посилюються як в'яжуча, так і припікаюча дії купрум сульфату на епітелій філаментів. На ньому з'являються численні виразки, що часто супроводжуються більш або менш потужними кровотечами. Усі ці порушення є необоротними. А стан піддослідних особин за концентрації 10 мг/дм ${ }^{3}$ токсиканта в середовищі відповідає сублетальній і летальній фазам процесу отруєння, які стрімко розвиваються одна за одною.

Висновки та перспективи подальших досліджень. За концентрації 0,1 мг/дм ${ }^{3}$ купрум сульфату у водному середовищі у U. rostratus, U. conus i C. piscinale розвивається компенсаторна тахікардія.

Стан піддослідних тварин відповідає другій фазі патологічного процесу, викликаного отруєнням організму цим токсикантом, - фазі стимуляції.

Збільшення його концентрації в середовищі до 1 і 10 мг/дм ${ }^{3}$ супроводжується прогресуючою брадикардією. Стан молюсків за 1 мг/дм токсиканта у водному середовищі відповідає депресивній фазі процесу отруєння, а за 10 мг/дм³ стрімко проявляються одна за одною дві останні його фази сублетальна й летальна.

Ці молюски можуть бути використані як індикаторні види в системі екологічного моніторингу.

Не з'ясованим залишилося значення концентрації купрум сульфату, яка відповідає першій фазі процесу отруєння, - фазі байдужості. Це може стати предметом подальших токсикологічних досліджень.

\section{Джерела та література}

1. Метелев В. В. Водная токсикология / В. В. Метелев, А. И. Канаев, Н. Г. Дзасохова. - М. : Колос, 1971. $-247 \mathrm{c}$.

2. Строганов Н. С. Биологический аспект нормы и патологии в водной токсикологии / Н. С. Строганов // Теорет. пробл. водн. токсикологии. Норма и патология. - М. : Наука, 1983. - С. 3-21.

3. Стадниченко А. П. Влияние ионов тяжелых металов на ритм сердечних сокращений у перловицевых / А. П. Стадниченко, Н. Н. Сластенко, О. В. Бондаренко и др. - 1990. - 24 с. - Деп. в УкрИНТЭИ 11.03.1990. - № 420.

4. Алексеев В. А. Основные принципы сравнительно токсикологического эксперимента / В. А. Алексеев // Гидробиол. журн. - 1981. - Т. 17, № 3. - С. 92-100.

5. Деркач М. П. Елементи статистичної обробки результатів біологічного експерименту /М. П. Деркач. Львів : Вид-во ЛДУ, 1963. - 67 с.

6. Лакин Г. Ф. Биометрия / Г. Ф. Лакин. - М. : Высш. шк., 1973. - 343 с.

7. Стадниченко А.П. Морфофізіологічні порушення шкірних покривів перлівницевих (Mollusca, Bivalvia, Unionidae) за дії на них купрум сульфата / А. П. Стадниченко, В. К. Гирин // Перспективні напрямки укр. науки. - Запоріжжя : ПГА, 2012. - С. 23-26.

8. Хлебович В. В. Акклимация животных / В. В Хлебович. - Л. : Наука, 1981. - 136 с.

9. Биргер Т. И. Метаболизм водных беспозвоночных в токсической среде / Т. И. Биргер. - Киев : Наук. думка, 1979. - $190 \mathrm{c}$.

10. Маляревская А. Я. Биохимические механизмы адаптации гидробионтов к токсическим веществам / А. Я. Маляревская // Гидробиол. журн. - 1985. - Т. 21, № 3. - С. 70-82.

11. Строганов Н. С. Действие сточных промышленных вод на водные организмы (новые пути решения проблемы) / Н. С. Строганов, А. П. Пожитков - М. : Изд-во МГУ, 1941. - 88 с.

Стадниченко Агнесса, Вискушенко Дмитрий. Влияние купрум сульфата водной среды на частоту сердцебиения перловицевых (Mollusca, Bivalvia, Unionidae). Исследуется влияние различных концентраций $\left(0,1,1,10\right.$ мг/дм $\left.{ }^{3}\right)$ купрум сульфата водной среды на физиологический статус наиболее широко распространенных и многочисленных в Украине перловицевых - Unio conus, U. rostratus, Colletopterum piscinale. В качестве тест-функции использован показатель частоты сердцебиения, устанавливаемый визуально у фистульных животных. При 0,1 мг/дм ${ }^{3}$ токсиканта в среде у перловиц развивается компенсаторная тахикардия, что соответствует фазе стимуляции процесса отравления. С возрастанием концентрации купрум сульфата в

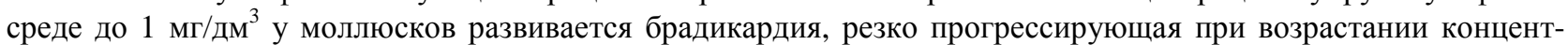

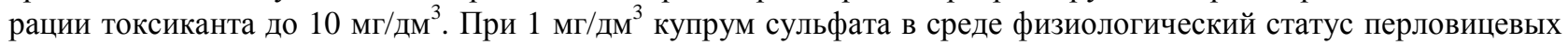


соответствует депрессивной фазе процесса отравления, а при 10 мг/дм³ этого поллютанта у них быстро следуют одна за другой завершающие его фазы - сублетальная и летальная.

Эти моллюски могут быть использованы в качестве индикаторных видов в системе экологического мониторинга.

Ключевые слова: перловицевые, купрум сульфат, ритм сердцебиения.

Stadnychenko Agnessa, Vyskushenko Dmytro. The Influence of Cuprum Sulphate of Water Environment on Unionides (Mollusca, Bivalvia, Unionidae) Heart Beat Frequency. The article focuses on the influence of the different concentrations $\left(0,1,1,10 \mathrm{mg} / \mathrm{dm}^{3}\right)$ cuprum sulfate of water environment on physiological state of Unio conus, U. rostratus, Colletopterum piscinale - the most widespred and numerous species from unionides in Ukraine. The heart beat frequency obtain visually from the fistulary animals have been used as the test-function. In solution which contain $0,1 \mathrm{mg} / \mathrm{dm}^{3}$ cuprum sulfate heart beat frequency sharply raisees in all reserched species. It is one from the protective compensatory adaptation correspond to the phase stimulation of poisoning process. With cuprum sulfate concentrations increase to $1 \mathrm{mg} / \mathrm{dm}^{3}$ bradycardia becomes evident in these animals. It sharply progresses if cuprum sulfate concentration increase to $10 \mathrm{mg} / \mathrm{dm}^{3}$. With $1 \mathrm{mg} / \mathrm{dm}^{3}$ cuprum sulfate physiological state of unionides corresnond to depressive phase of poisoning process. With $10 \mathrm{mg} / \mathrm{dm}^{3}$ this matter in environment result in the rapid go after of two last phases of poisoning process - sublethal and lethal.

These unionides maybe use in the ecological monitoring system as species-indicators.

Key words: unionides, cuprum sulphate, heart rhythm.

Стаття надійшла до редколегії 06.09.2015 p.

УДК 595.745/502.7(477-924.52)

Катерина Сухомлін,

Василь Чумак,

Анна Омелянчук

\section{Аналіз видового складу імаго волохокрильців (Trichoptera) Угольського заповідного масиву Карпатського біосферного заповідника}

У межах Угольського заповідного масиву Карпатського біосферного заповідника зареєстровано 10 видів волохокрильців із восьми родів. Домінантним і розповсюдженим є Limnephilus rhombicus. Імаго волохокрильців активно літають із квітня до середини серпня. Найвищу активність льоту зареєстровано із середини квітня до початку червня. Упродовж решти вегетаційного сезону імаго трапляється в невеликій кількості. Найбільшу кількість видів (60 \%) відзначено в лісі, а найменшу (40\%) - на межі лісу та вікна. Найбільшу кількість особин різних видів зареєстровано в центрі вікна (50 \%), а найменшу $(22,3 \%)$ - у лісі. Зі збільшенням висоти ділянок над рівнем моря зростає видовий склад, а чисельність зібраних імаго знижується. Експозиція схилу впливає на видовий склад імаго волохокрильців. Так, Halesus digitatus зареєстровані лише на північних схилах, Ironoquia dubia - на південних, Rhyacophila nubila - при східній експозиції схилу.

Ключові слова: Trichoptera, видове різноманіття, поширення, Угольський заповідний масив, Карпатський біосферний заповідник.

Постановка наукової проблеми та її значення. Волохокрильці - відносно невеликий ряд гетеротопних комах. Вони відіграють важливу роль у біоценозах, оскільки личинки й лялечки, а також i дорослі особини слугують кормом для різних риб та птахів. Личинки волохокрильців у прісних водоймах становлять істотну частину бентосу й можуть бути використані під час біологічного аналізу води як індикаторні організми рівня забруднення. Здебільшого личинки волохокрильців є олігосапробами мешканцями чистої води [1].

Аналіз дослідження цісї проблеми. Перші згадки про волохокрильців (Trichoptera) України простежено в роботі Г. Белке [7]. Науковець, порівнюючи фауну Поділля й Карпат, називає чотири види, які мешкають у Карпатах: Phryganea grandis, Agrypnia varia, Limnephilus rhombicus, Anabolia laevis. Польський ентомолог Я. Дзідзелевич зареєстрував на території Східних Карпат і Прикарпаття

(C) Сухомлін К., Чумак В., Омелянчук А., 2015 